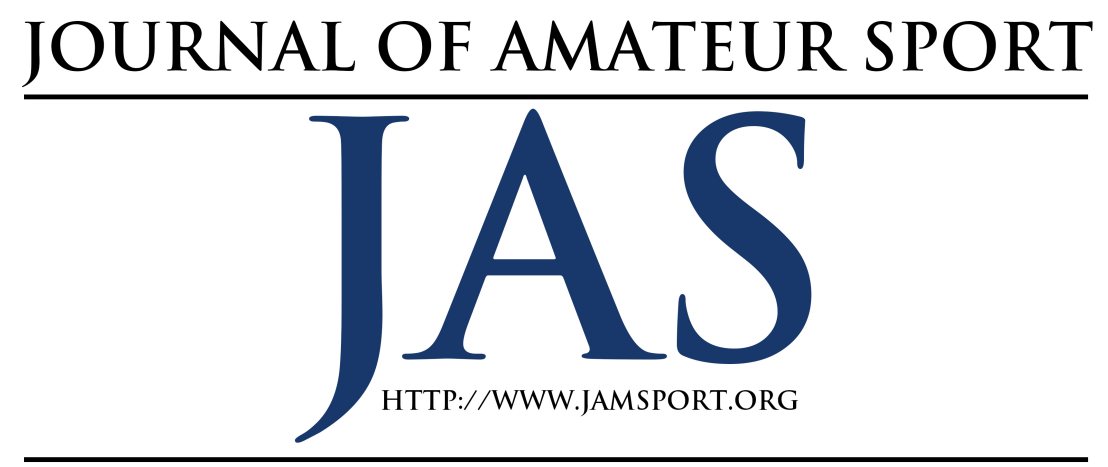

\title{
A Dying Trend or a Viable Option: Dual-Role Athletic Department Employees
}

\author{
Lawrence Brady ${ }^{1} \quad$ Tracy Trachsler ${ }^{2}$ \\ ${ }^{1}$ State University of New York. College at Cortland \\ ${ }^{2}$ Cazenovia College
}

As athletic departments at the college/university level are trying to creatively balance the financial demands of supporting athletic programs with employee satisfaction and departmental needs, the topic of the dual-role employee tends to appear in conversation. The question remains, with all of the demands, in both administration and coaching, is it possible for a single person to successfully accomplish the job obligations in both areas?

$\mathrm{T}$ he debate over the viability of the dual-role coach/athletic director within college sports is at a critical juncture. In the most recent iterations of the National Collegiate Athletic Association (NCAA) applications for new membership, specific language has been included to discourage or eliminate dual-role positions. Notably addressed within Division II and Division III, the sentiment is that the dualrole employee can no longer adequately handle obligations that come with undertaking both positions.
Historically, the coach/administrator model was adopted by a number of schools to capitalize upon the knowledge, expertise, and availability of qualified staff who could transition into leadership roles in athletic programs (Judge \& Judge, 2009). Many times, it was the head football coach who was viewed as the candidate with the highest potential to assume the head athletic director obligations (Wong, 2014). The head football coach, typically, had the most experience in dealing with large revenue streams and expenses, large operations, and a large number of student-athletes and staff. 
It was perceived that these traits would serve the department well when determining who should be the administrator (Belzer, 2015). In consideration of budgets within athletic departments, much of the decisionmaking on this topic related to the bottom line.

Researchers assert NCAA athletic programs are dominated by an unsustainable commercial model in which institutions are utilizing a cycle of spending that leaves many institutions operating in the red (Bowen \& Levin, 2003; Cooper \& Weight, 2011; Schulman \& Bowen, 2001; Sparvero \& Warner, 2013; Tobin, 2005; Weaver, 2011). Still, such spending continues because athletic victories are perceived to generate revenue streams for many institutions, particularly at the Division I level in revenue-generating sports. The revenue streams are intended to be used to further augment athletic programs, which they believe will help generate future athletic success (Getz \& Siegfried, 2012; Sparvero \& Warner, 2013; Weaver, 2011). Researchers claim that this commercial model, while most evident in Division I, is not entirely unique to Division I (Bowen \& Levin, 2003; Schulman \& Bowen, 2001; Sparvero \& Warner, 2013; Tobin, 2005). Researchers have found similarities in practices across all three divisions of competition. The high stakes tied to athletic victories has fostered an environment where many intercollegiate athletic departments have been granted authority to operate autonomously within the university structure to achieve the desired athletic outcome (Frey, 1994).

In today's high-stakes sport environments, with such financial issues, and associated ethical concerns over improper operations and behaviors (Orlando, 2012), is the dual-role coach/athletic director really still an option worth fighting for as a logical opportunity for cost-saving and operational streamlining? The mounting job obligations of both roles and the accountability within both roles would cause even those who support the notion to honestly question the ability to do it all and do it all well.

\section{Background}

Susan Cassidy-Lyke, of Malloy College (NCAA Division II), wrote an article published in Athletic Management in July 2015 making a case for the "Dual Threat" employee (Cassidy-Lyke, 2015). In the byline she wrote, "Can today's athletic director successfully double up as a coach? With an ongoing check of priorities and a solid organizational plan, the answer is yes."

In line with her assertion, there is evidence of individuals still attempting dualrole positions within NCAA member institutions. Most recently, in June of 2015, George O'Leary of NCAA Division I member University of Central Florida accepted the title of Interim Director of Athletics in addition to his duties as Head Football Coach (Green, 2015). In an interview, he was documented as saying that if he felt he was inefficient in either of his roles, he would leave the role (Green, 2015). Sources reported that O'Leary wanted to stay on as athletic director and give up his coaching responsibilities; however, there were concerns over his lack of administrative experience (Wolken, 2015). O'Leary later stated he did not want the athletic director role (Heil, 2015). 
Ultimately, O'Leary resigned from both positions in October of 2015, less than six months after assuming both roles, making way for Danny White to become the fulltime director of athletics (Green \& Bianchi, 2015).

Barry Alvarez of the University of Wisconsin-Madison and Tom Osborne of Nebraska were noted as two other individuals able to manage dual role obligations at NCAA Division I institutions (Green, 2015). Alvarez held the dual role for just one year, in 2004, before stepping away as head football coach. Since then, he has only assumed dual-role obligations on an asneeded basis but has not formally held both positions within the institution. Osborne held his dual-role position at the University of Nebraska for a number of years in the 1970's; however, neither of the positions were as the head coach or head athletic director of the program (Green, 2015).

Historically, in Division II and Division III programs, where departmental budgets are smaller in comparison to Division I, the dual-role was a great option. An example of a Division III athletic director with a dual role was Bob Ward from St. John Fisher College in Rochester, New York. He held the position of both Athletic Director and Men's Varsity Basketball coach for fifteen years. In a personal conversation with him, Mr. Ward indicated that as the athletic department grew, both the coaching position and the administrative position began to suffer because of the lack of time to do both properly (B. Ward, personal communication, March 8, 2016). The NCAA membership, in recent business sessions, has proposed legislation in alignment with this sentiment.

\section{Strategic Elimination of Dual Role Positions}

Aside from the employees consciously selecting one position over dual roles, the NCAA membership is working to reduce and eliminate such positions. One of the most visible examples of the issue could be witnessed at the 2015 NCAA Division II business session (Stark, 2015). Athletic directors initially voted in favor of eliminating dual-role positions within the current member institutions. After additional debates within the session, the proposal to eliminate current dual-role positions was then defeated. The primary causes for reconsideration were related to the ability of the colleges to continue to operate autonomously based upon their needs and the increased financial pressures inherent with having to add a new position (Stark, 2015). Some members felt they can handle the obligations - such as Susan Cassidy-Lyke of Malloy College who wrote the aforementioned article. This is just one such example of colleges creatively trying to develop organizational structures that allow for successful operation in sport while still achieving departmental priorities with limited available resources.

In spite of the perception that it can be done, new opportunities for dual-role employment as coach and athletic director in colleges are diminishing. Recently established Division II legislation for any new members requires that, "The institution shall demonstrate that it has personnel to operate the intercollegiate athletics program at the Division II level, including, but not limited to: (1) A full-time director of athletics, whose primary responsibility is overseeing the administration of the 
department of athletics and who has no coaching responsibilities..." (NCAA, 2015a, p. 3). At the Division III level, the membership application for 2016 includes the following language, "Although not a requirement, as a best practice it is recommended that the Director of Athletics should serve as a primary athletics administrator and should not have other major responsibilities (e.g., should not also serve as a coach)" (NCAA, 2015b, p. 1).

\section{Personal Challenges Associated with the Dual Role}

Aside from concerns over specific jobrelated indicators of success, many individuals identified personal challenges they faced when trying to balance the responsibilities of both an Athletic Director and coach. Researchers have studied the effects of job-related factors in athletic personnel job satisfaction and burnout (Vealey et al., 1992). The findings suggest that pay and job satisfaction alone are not enough to keep an individual in a position (Ryan \& Sagas, 2009). Both coaches and athletic directors have been the subject of job-related stress research and both roles have a number of stressors and demands with which the professionals struggle (Levy, Nicholls, Marchant, \& Polman, 2009). Frey (2007) reported that one of the major stressors in Division I coaching was the pressure associated with trying to accomplish too many obligations and responsibilities associated with their job. That stressor and, "physical hardship, wanting more free time, attraction to an alternative activity, interference with family life, losing the passion for coaching, losing consistently, and consistently feeling frustrated or unhappy," (Frey, 2007, p. 53) were associated with the coaches noting declines in concentration, trouble with decision making, and increases in emotional outbursts. Similarly, within the administrative roles, Ryska (2002) found that role demands and the degree to which they are pursued are directly related to the amount of stress perceived by athletic directors. Ryska (2002) wrote, "It has been suggested that the various role demands placed on athletic personnel may produce higher levels of stress than those found in other professions involving a high degree of interpersonal interaction (Horine, 1994; Kelly, 1994)" (p. 196). In spite of CassidyLykes statement that prioritizing and planning can help the dual role employee execute their job functions, researchers and practitioners alike note challenges to sustaining this model.

\section{Organizational Implications of Maintaining the Dual Role}

Accountability to an authority figure, along with successful division of work, is to ensure organizational effectiveness (Schein, 1985). While Cassidy-Lykes (2015) presents a compelling case for prioritization and organization in alignment with effective operations, it is only a piece of the puzzle. Division of labor and specialization are also necessary components for effectiveness (Schein, 1985).In examinations of other organizational models, CEOs of corporations are reporting up to boards of directors or some form of ownership. In addition, one study showed that companies with separate $\mathrm{CEO}$ and Chairman of the Board roles had significantly higher longterm shareholder returns than companies 
with a dual-role (Hodgson, 2014). At a corporate level, the CEOs primary role is to manage the company, whereas the role of the Board is to oversee that management and provide independent insights if any challenges arise. By combining those two roles, the independent view is lost. Similarly, the systems of checks and balances and the direct report function that ensures accountability is compromised in the dualrole model (Hodgson, 2014).By combining those two roles, that independent view is lost, and some resemblance of checks and balances therefore the direct report function to ensure accountability is compromised in the dual-role model (Hodgson, 2014). Structurally, having a dual-position has the potential for disruptive organizational behaviors.

It is seemingly unrealistic to think in this day in age with marketing, social media, fundraising/development demands, that one can successfully devote $100 \%$ effort and ability to each of these areas successfully (Belzer, 2015). As Cindy Hartmann, Florida State University's Deputy Athletics Director of Administration stated, "We've gotten so complex... we need people with levels of expertise in a whole myriad of areas we didn't need years ago" (Hobson \& Rich, 2015, para. 9). Via an honest self-assessment one would most likely be able to identify an area of job neglect simply due to the normal restrictions of days in the week and working hours. Some may believe it is possible to do it all, but is it possible to do it all well? Someone or something inherently suffers from the decision, and as administrators and coaches can we ensure that our constituents are not suffering from our attempts to "do it all?" In an increasingly competitive collegiate athletic environment, athletic departments must respond to demands within the market, which many times requires hiring additional staff members with increased specialization in order to remain successful (Hobson \& Rich, 2015).

\section{Conclusions}

Many have found working within athletic departments enjoyable and rewarding, but many also are quick to note the inherent challenges and stresses that accompany such career decisions (Frey, 2007). With the popularity of high-stakes college sports in American culture, college national championships running nearly year round, is there ever enough time to realistically budget to multiple job roles? The demand for sport is so high, that a dual role seems nearly impossible in this day and age if the ultimate goal is quality outputs versus quantity. While Susan Cassidy-Lyke and colleagues may disagree, it would appear that the consensus, moving forward, is that it is better for professionals to specialize and select one role for the benefit of all of those within the athletic department. 


\section{References}

Belzer, J. (2015). The dynamic role of the modern day college athletics director. Forbes. Retrieved from http://www.forbes.com/sites/jasonb elzer/2015/02/19/the-dynamic-roleof-the-modern-day-college-athleticsdirector/\#45884da32002

Bowen, W. G., \& Levin, S. A. (2003). Reclaiming the game: College sports and educational values. Princeton, NJ: Princeton University Press.

Cassidy-Lyke, S. (2015, June/July). Dual threat. Athletic Management. Retrieved from

http://www.athleticmanagement.co $\mathrm{m} /$ content/dual-threat

Cooper, C., \& Weight, E. (2011).

Investigating NCAA administrator values in NCAA Division I athletic departments. Journal of Issues in Intercollegiate Atbletics, 4(2), 74-89.

Frey, J. H. (1994). Deviance of organizational subunits: The case of college athletic departments. Journal of Sport and Social Issues, 18(2), 110-122.

Frey, M. (2007). College coaches' experiences with stress- "problem solvers" have problems too. The Sport Psychologist, 21, 38-57.

Getz, M., \& Siegfried, J. J. (2012). College sports: The mystery of the zero-sum game. Change: The Magazine of Higher Learning, 44(1), 52-59.

Green, S. (2015). George O'Leary steps down as UCF interim athletics director. Orlando Sentinel. Retrieved from

http://www.orlandosentinel.com/sp orts/ucf-knights/os-ucf-george-oleary-athletics-director-20151012story.html

Green, S., \& Bianchi, M. (2015). UCF football coach George O'Leary is retiring. Orlando Sentinel. Retrieved from

http://www.orlandosentinel.com/sp orts/ucf-knights/

Heil, J. (2015). George O'Leary steps down as UCF's interim AD. Central Florida Future. Retrieved from http://www.centralfloridafuture.com /story/sports/2015/10/12/espngeorge-o-leary-step-down-ucfinterim-ad/73818270/

Hobson, W. \& Rich, S. (2015, December 29). As college sports revenues spike, coaches aren't the only ones cashing in. W ashington Post. Retrieved from https://www.washingtonpost.com/s ports/as-college-sports-revenuesspike-coaches-arent-only-onescashing-in/2015/12/29/bbdb924eae15-11e5-9ab0884d1cc4b33e_story.html?utm_term $=.7 \mathrm{ff} 1 \mathrm{aa} 087992$

Hodgson, P. (2014, October 21). Should the chairman be the CEO? Fortune. Retrieved from http://fortune.com/2014/10/21/ch airman-ceo/

Judge, L. W., \& Judge, I. L. (2009).

Understanding the occupational stress of interscholastic athletic 
directors. The ICHPER-SD Journal of Research in Health, Physical Education, Recreation, Sport \& Dance, 4(2), 37-44.

Levy, A., Nicholls, A., Marchant, D., \& Polman, R. (2009). Organisational stressors, coping, and coping effectiveness: A longitudinal study with an elite coach. International Journal of Sports Science and Coaching, 4(1), 31-45.

National Collegiate Athletic Association. (n.d.) So you want to be an athletics director. Retrieved from http://www.ncaa.org/governance/so -you-want-be-ad

National Collegiate Athletic Association. (2015a). 2016 Application for Division II Membership. Retrieved from http://www.ncaa.org/sites/default/f iles $/ 2016 \% 20$ DII $\% 20$ Membership $\%$ 20Application \%20Instructions.pdf

National Collegiate Athletic Association. (2015b). Model for Success for a Division III Atbletics Program. Retrieved from http://www.ncaa.org/sites/default/f iles/Model $\% 2 B D I I I \% 2 B A t h l e t i c s \% 2$ BProgram-December\%2B2013.pdf

Orlando, M. (2012). Leadership implications and ethical solutions of athletic directors in producing a successful Division I-A football program. Review of Management Innovation \& Creativity, 5 (14), 81-87.

Ryan T. D., Sagas, M. (2009). Relationships between pay satisfaction, work-family conflict, and coaching turnover intentions, Team Performance
Management: An International Journal, 15(3/4), $128-140$.

Ryska, T. A. (2002). Leadership styles and occupational stress among college athletic directors: The moderating effect of program goals. Journal of Psychology, 136(2), 195-213.

Schein, E. H. (1985). Organizational psychology ( $3^{\text {rd }}$ ed.). Englewood Cliffs, NJ: Prentice-Hall.

Schulman, J. L., \& Bowen, W. G. (2001). The game of life. Princeton, NJ: Princeton University Press.

Sparvero, E. S., \& Warner, S. (2013). The price of winning and the impact on the NCAA community. Journal of Intercollegiate Sport, 6(1), 120-142.

Stark, R. (2015). Division II athletics director proposal narrowly fails: Members approve similar compliance administrator proposals. NCAA.org. Retrieved from http://www.ncaa.org/about/resourc es/media-center/news/division-iiathletics-director-proposal-narrowlyfails

Tobin, E. M. (2005). Athletics in Division III institutions: Trends and concerns. Pbi Kappa Pbi Forum, 85(3), 24-27.

Vealey, R. S., Udry, E. M., Zimmerman, V., \& Soliday, J. (1992). Intrapersonal and situational predictors of coaching burnout. Journal of Sport and Exercise Psychology, 14, 40-58.

Weaver, K. (2011). A game change: Paying for big-time college sports. Change: 
The Magazine of Higher Learning, 43(1), 14-21.

Wolken, D. (2015). George O’Leary wants to stay on as athletic director at Central Florida. USAToday. Retrieved from

http://www.usatoday.com/story/spo rts/ncaaf/aac/2015/09/01/georgeoleary-permanent-athletic-directorcentral-florida-step-downcoach/71507104/

Wong, G. (2014). The path to the athletic director's office. Sports Business Daily. Retrieved from http://www.sportsbusinessdaily.com /Journal/Issues/2014/06/09/InDepth/Wong-olumn.aspx 